\title{
GOOD GOVERNANCE DALAM PERSPEKTIF HUKUM ISLAM
}

\author{
(TINJAUAN USUL FIQIH)
}

\author{
Rahmawati $^{1}$
}

\begin{abstract}
Abstrak
Good governance adalah istiah yang digunakan ditentukan dalam literatur pembangunan untuk menggambarkan bagaimana lembaga-lembaga publik melakukan urusan publik dan mengelola sumber daya publik untuk menjamin realisasi hak asasi manusia. Pemerintahan menggambarkan "proses pengambilan keputusan dan proses dengan mana keputusan diimplementasikan (atau tulak diimplementasikan)'. Good Governance Ini dapat berlaku untuk perusahaan, internasional, nasional, pemerintahan lokal atau interaksi antara sektor-sektor lain dari masyarakat. Konsep "good governance' sering muncul sebagai model untuk membandingkan ekonomi (yang) tidak efektif atau lembaga politik dengan ekonomi yang layak dan juga lembaga politik

Karena pemerintah yang paling "sukses" dalam dunia kontemporer adalah negara demokrasi liberal yang terkonsentrasi di Eropa dan Amerika negara-negara 'lembaga senng menetapkan standar yang digunakan untuk membandingkan negara-negara lain institusi Karena pemerintahan yang baik panjang dapat difokuskan pada suatu bentuk pemerintahan, organisasi bantuan dan otoritas negara-negara maju sering akan fokus arti pemerintahan yang baik untuk satu sel persyaratan yang sesuai dengan agemla organisasi, membuat "good governance" menyiratkan banyak hal yang berbeda dalam konteks yang berbeda.
\end{abstract}

\section{l.atar Belakang}

Pemerintahan yang bersih umumnya berlangsung di negara yang masyarakatnya menghormati hukum Pemerintahan yang seperti ini juga disebut sebagai pemerintahan yang baik (good governance). Pemerintahan yang baik itu hanya bisa dibangun melalui pemerintahan yang bersih (clean govement) dengan aparatur birokrasinya yang terbebas dari KKN Dalam rangka mewujudkan clean goverment, pemerintah harus memiliki moral dan proaktif mewujudkan partisipasi serta check and balances. Tidak mungkin mengharapkan pemerintah sebagai suatu komponen dari proses politik memenuhi prinsip clean government dalam ketiadaan partisipasi

Secara umum usul fiqih merupakan metode pengkajian Islam pada umumnya dan dalam sejarah kebudayaan Islam inilah satu-satunya metode khas Islam yang berkembang, namun dalam pengertian khusus, usul fiqih adalah suatu metode penemuan hukum syari'ah Sebagai metode penemuan hukum, usul fiqih merupakan bagian dari metode penelitian hukum Islam secara umum. Penelitian hukum Islam secara keseluruhan dibedakan kedalam dua bidang besar, yaitu penelitian hukum Islam deskriptif dan penelitian hukum Islam preskriptif. Penelitian hukum Islam deskriptif meneropong hukum Islam sebagai suatu fenomena sosial yang berinteraksi dengan gejala-gejala sosial lainnya

Dalam kaitan ini hukum Islam dapat dilihat baik sebagai variable independen (bebas) yang mempengaruhi masyarakat maupun sebagai variable dependen (terikat) yang dipengaruhi oleh masayarakat Dalam penelitian model ini biasanya digunakan berbagai pendekatan yang

${ }^{1}$ Rahmawati adalah Tenaga Pengajar Pada STAIN Manado Jurusan Syari'ah 
dikembangkan dalam ilmu-ilmu sosial dan kemanusiaan, seperti pendekatan sejarah, ${ }^{2}$ pendekatan sosiologi, pendekatan politik, pendekatan antropologi, dan seterusnya

Pendekatan hukum Islam preskriptif bertujuan menggali norma-norma hukum Islam dalam tataran das sollen.yaitu norma-norma yang dipandang ideal untuk dapat mengatur tingkah laku manusia dan menata kehidupan bermasyarakat yang baik Usul fiqih termasuk ke dalam bidang penelitian hukum Islam presktiptif, yang bertujuan menemukan norma-norma syari'ah untuk merespons berbagai permasalahan dari sudut pandang normatif.

Dalam pandangan yang tidak tepat dari banyak orang Muslim, dengan hukum Islam biasanya hanya dimaksudkan kumpulan peraturan konkret berupa halal, haram, makruh, mubah, atau sunat saja Bila disebut hukum Islam yang terbayang oleh mereka hanyalah kategori-kategori tersebut. Pengertian seperti ini jelas tidak tepat Selain terdiri atas kategori penilaian seperti halal atau haram.

hukum Islam juga terdiri atas kategori-kategori relasional. Lebih penting lagi adalah bahwa hukum Islam sesunggguhnya terdiri atas norma-norma berjenjang (berlapis).

Di zaman lampau pelapisan itu terdiri atas dua tingkat norma: peraturan hukum kongkret (al-ahkam al-far'iyyah), dan asas-asas umum (al-usul al-kulliyyah). Asas-asas umum itu dalam pandangan para ahli hukum Islam klasik mencakup kategori yang luas sehingga meliputi pula nilai-nilai dasar (al-qiyam al-asasiyah) hukum Islam. Oleh karena itu untuk praktisnya normanorma iersebut dibagi saja kedalam tiga tingkatan, yaitu (1) peraturan konkret, (2) asas-asas umum, dan (3) niilai-nilai dasar Nilai-nilai dasar hukum Islam adalah nilai-nilai dasar agama Islam sendiri, karena (tukum Islam berlandaskan nilai-nilai dasar Islam Di dalam al-Qur'an secara harfiah dan secara implisit banyak ditemukan nilai-nilai dasar Islam yang menjadi nilainilai dasar hukum Islam juga Misalnya tauhid, keadilan, persamaan, kebebasan, kemaslahatan, persaudaraan, syura, amanah, tadilah, tasamuh, ta'awun dan sebagainya

Dari nilai-nilai dasar itu diturunkan asas-asas umum hukum Islam dan dari asas umum diturunkan peraturan hukum konkret Dengan kata lain kita dapat mengatakan bahwa suatu peraturan hukum konkret berlandaskan atau dipayungi oleh asas umum dan asas umum pada gilirannya berlandaskan atau dipayungi oleh nilai dasar Misalnya dari nilai dasar persamaan dapat diturunkan asas umum dalam kehidupan politik bahwa laki-laki dan perempuan mempunyai hak politik yang sama. Dari asas itu diturunkan peraturan konkret (al-hukm al-far'i) bahwa mubah hukumnya perempuan menjadi presiden

Dalam penelitian hukum Islam penggunaan usul fiqih sebagaimana banyak berlaku selama ini lebih banyak terarah kepada penelitian peraturan hukum konkret. Apa hukum perempuan menjadi kepala Negara?.Seharusnya penelitian hukum Islam juga diarahkan kepada penggalian asas-asas dengan mempertimbangkan pendekatan peningkatan norma sehingga lebih mudah merespons berbagai perkembangan masyarakat dari sudut hukum syari'ah. Dalam makalah kali ini masalah goodgovernance dalam perspektif hukum Islam akan dilihat dengan teori peningkatan norma dalam usul fiqih.

${ }^{2}$ Pendekatan ini banyak digunakan oleh pengkaji hukum Islam dari Barat seperti Haraid Motiki, The Origins of Islamic Jurisprudence: Meccan Fiaih before the Classical Schools (Leiden-Boston-Koln: Brill, 2002). 


\section{PEMBAHASAN}

\section{A. GOOD GOVERNANCE.}

Menjelang berlasungnya reformasi politik di Indonesia atau sekitar tahun 1996, beberapa lembaga international seperti UNDP dan World Bank, memperkenalkan terminologi baru yang disebut sebagai good governance. Popularitas terminologi ini muncul dikalanean pemerintah, akademisi, dan lembaga swadaya masyarakat sejalan dengan pemberian bantuan ${ }^{3}$ yang diarahkan pada pengembangan good governance.

Karena sangat gencar dipromosikan maka sekarang ini istilah good governance menjadi kata yang sering diucapkan dalam berbagai ruang diskusi di Indonesia, seperti halnya istilah demokrasi dah otonomi. Kita dapat mendengarkannya di setiap diskusi, seminar, lokakarya, pidato pejabat maupun berita atau artikel opini di media massa. Dalam banyak kesempatan, istilah governance dibiarkan dalam bentuk aslinya karena memang sulit dicari padanannya yang tepat. ${ }^{4}$ Banyak pula yang meneijemahkannya menjadi tata pemerintahan, ${ }^{5}$ penyelenggaraan Negara, atau cukup diartikan dengan penyelenggaraan ataupun pengelolaan (manajemen).

Kata governance berasal dari kata to govern (yang berbeda maknanya dengan to command atau to order) yang artinya memerintah. Governance atau pemerintah adalah pengarahan yang berkewenangan dan pengaturan atas kegiatan orang-orang dalam sebuah negara, negara bagian, kota, dan sebagainya. Dapat diartikan juga lembaga atau badan yang menyelenggarakan pemerintahan ncBnra bagian, kota, dan sebagainya. Bintoro Tjokroamijoyo 2000, dalam bukunya GoodGovernance (Paradigma Baru Manajemen Pembangunan) mengarahkan governance artinya, memerintah, menguasai, mengurus, mengelola Pidato Presiden di depan DPR 16 Agustus 2000 menerjemahkan istilah governance dengan pengelolaan.

Dalam governance ada 3 komponen yang sejajar, setara, saling mengontrol, untuk menghindari terjadinya eksploitasi satu terhadap lainnya, yaitu: pemerintah, dunia usaha, dan masyarakat Dalam realisasinya peran pemerintah masih lebih dominan. Karena permasalahan yang ditangani cenderung makin meningkat Governance semula diartikan pemerintahan, kemudian berkembang dan popular dengan sebutan kepemerintahan

Secara konseptual pengertian good (baik) dalam istilah Good Governance (kepemerintahan yang baik), mengandung dua pemahaman:

1. Nilai-nilai yang menjunjung tinggi keinginan/kehendak rakyat dan nilai-nilai yang dapat meningkatkan kemampuan rakyat dalam mencapai tujuan nasional, kemandirian, pembangunan berkelanjutan dan keadilan sosial.

2. Aspek-aspek fungsional dari pemerintahan yang efisien dan efektif dalam pelaksanaan tugasnya untuk mencapai tujuan dimaksud. ${ }^{6}$

${ }^{3}$ Agus Dwiyanto, Teladan dan Pantangan dalam Penyelenggaraan pemerintahan dan Otonomi Daerah (Yogyakarta: PSKK UGM, 2003), hlm. 102-103.

${ }^{4}$ Ibid, hlm. 60 .

${ }^{5}$ Ibid.,hlm. 175-176.

6 Muhammad Irfan, Akuntabilitas dan Good Governance (Jakarta: Departeman RI Sekretariat Jenderal Biro Organisasi dan Tata laksana, 2007), hlm. 24-25. 
Oleh karena itu dapat dikatakan Good Governance berorientasikan pada 2 hal pertama yaitu pencapaian tujuan nasional, kedua pemerintahan yang ideal (efisien dan efektif) dalam melakukan pencapaian tujuan nasional Hakekatnya penyelenggaraan pemerintahan atau kepemerintahan ditujukan kepada terciptanya fungsi pelayanan publik. aspek:

Dari aspek pemerintah (goverment), Good Governance dapat dilihat melalui aspek-

1. Kebijakan Hukum, perlindungan kebebasan sosial, politik, ekonomi

2. Kompetensi administrasi dan transparansi.

3. Desentralisasi

4. Penciptaan pasar yang kompetitif

United Nation Development Program (UNDP) pada tahun 1997 mendefinisikan Good Gowrnance sebagai berikut: Kepemerintahan adalah pelaksanaan kewenangan/kekuasaan di bidang ekonomi, politik, dan administrative untuk mengelola berbagai urusan Negara pada semua tingkatan dan merupakan instrumen kebijakan Negara untuk mendorong terciptanya kondisi kesejahteraan, integritas, dan kohesivitas sosial dalam masyarakat Dengan kata lain suatu hubungan yang sinerjik dan konstruktif di antara Negara, sector swasta, dan masyarakat. ${ }^{7}$

Adapun terjemahannya, govemaine menunjuk pada pengertian bahwa kekuasaan tidak lagi semata-mata dimiliki atau menjadi urusan pemerintah Governance menekankan pada pelaksanaan fungsi governing secara bersama-sama oleh pemerintah dan institusi-institusi lain, yaitu LSM, perusahaan swasta maupun warga Negara Bahkan institusi non pemerintah ini dapat saja memegang peran dominan dalam governance tersebut, atau bahkan lebih dari itu pemerintah tidak mengambil peran apapun.

Perspektif governance mengimplikasikan terjadinya pengurangan peran pemerintah, pemerintah sebagai institusi tidak bisa ditinggalkan begitu saja Sehingga Negara memiliki 6 prinsip diantaranya:

1. Dalam kolaborasi yang dibangun. Negara tetap bermain dalam figur kunci namun tidak mendominasi, serta memiliki kapasitas mengkoordinasi aktor-aktor pada institusiinstitusi semi dan non-pemerintah untuk mencapai tujuan-tujuan publik.

2. Kekuasaan yang dimiliki Negara harus ditransformasikan, dari yang semula dipahami sebagai "kekuasaan atas" menjadi "kekuasaan untuk" menyelenggarakan kepentingan, memenuhi kebutuhan, dan menyelesaikan masalah publik.

3. Negara, NGO, swasta, dan masyarakat lokal merupakan aktor-aktor yang memiliki posisi dan peran yang saling menyeimbangkan untuk tidak menyebut setara

4. Negara harus mampu mendesain ulang struktur dan kultur organisasinya agai siap dan mampu menjadi katalisator bagi institusi lainnya untuk menjalin sebuah kemitraan yang kokoh, otonom, dan dinamis.

5. Negara harus melibatkan semua pilar masyarakat dalam proses kebijakan mulai dari formulasi, implementasi, dan evaluasi kebijakan, serta penyelanggaraan layanan publik.

6. Negara harus mampu meningkatkan kualitas responsivitas, adaptasi, dan akuntabilitas publik dalam penyelenggaraan kepentingan, pemenuhan kebutuhan, dan penyelesaian masalah publik

Sementara itu, good governance memiliki sepuluh prinsip,

${ }^{7}$ Ibid., hlm. 26-27. 
1)Partisipasi: warga memiliki hak (dan mempergunakannya) untuk menyampaikan pendapat, bersuara dalam proses perumusan kebijakan

2) Penegakan hukum, hukum diberlakukan bagi siapapun tanpa pengecualian, hak asasi manusia dilindungi, sambil tetap memperhatikan nilai-nilai yang hidup dalam masyarakat

3) Transparansi penyediaan informasi tentang pemerintahan bagi publik dan dijaminnya kemudahan di dalam memperoleh informasi yang akurat dan memadai

4) kesetaraan: adanya peluang yang sama bagi setiap anggota masyarakat untuk beraktivitas/berusaha.

5) Daya tanggap pekanya para pengelola instansi publik terhadap aspirasi masyarakat

6) Wawasan ke depan pengelolaan masyarakat hendaknya dimulai dengan visi, misi, dan strategi yang jelas.

7) Akuntabilitas pertanggungjawaban para penentu kebijakan kepada para warga

8) Pengawasan publik: terlibatnya warga dalam mengontrol kegiatan pemerintah, termasuk parlemen

9) Efektifitas dan efisiensi: terselenggaranya kegiatan instansi publik dengan menggunakan sumber daya yang tersedia secara optimal dan bertanggungjawab. Indikatornya antara lain pelayanan mudah, cepat, tepat dan murah.

10) Profesionalisme: tingginya kemampuan dan moral para pegawai pemerintah, termasuk parlemen.

Dari berbagai prinsip di atas dapat disimpulkan bahwa sistem administrasi good governance haruslah melibatkan banyak pelaku, jaringan, dan institusi di luar pemerintah untuk mengelola masalah dan kebutuhan publik. ${ }^{8}$ Dengan demikian dalam penyelesaian masalah dan kepentingan publik selalu melibatkan multi-slakeholders dari berbagai lembaga yang terkait dengan masalah dan kepentingan publik itu Stakeholders dalam tata pemerintahan (governance) tersebut memiliki kedudukan yang setara dan hanya diikat oleh suatu jaringan dan prosedur yang sengaja diciptakan untuk menfasilitasi mereka dalam perumusan, pelaksanaan, monitoring, dan juga evaluasi kebijakan.

\section{B. Langkah-langkah Menerapkan Good Governance}

Bersikap apatis dan menunggu hanya akan semakin menjauhkan harapan terwujudnya good governance pada momentum otonomi daerah Langkah terdekat yang harus diperhatikan oleh pemerintah propinsi dan kabupaten/kota dalam rangka menyiapkan diri sebagai katalisator dan koordinator bagi institusi semi pemerintah dan non pemerintah dalam bereksperimen mewujudkan good local governance adalah membenahi permasalahan dan menyembuhkan penyakit yang diidapnya Permasalahan sekarang adalah, bagaimana memperdayakan seluruh komponen birokrasi pemerintahan meliputi aspek SDM, kelembagaan, dan tatalaksanaannya agar mampu menjadi aparatur pemerintahan yang profesional

Dalam hal ini, yang pertama-tama dipahami adalah reformasi birokrasi bukan berarti melakukan perombakan secara besar-besaran atau menyeluruh. Misalnya dengan segera menggantiseluruh atau sebagian besar struktural atau pegawai negeri sipil yang ada dengan yang baru Bisa dibayangkan betapa sulit mengganti sekian puluh ribu pejabat struktural atau 4,1 juta PNS dalam waktu singkat Mengingat hal itu dan juga karena tidak seluruh komponen dalam sistem birokrasi mengidap "penyakit" atau tidak dapat berfungsi dengan baik, maka upaya yang realistis dilakukan adalah dengan memperbaiki komponen-komponen yang rusak di daiam sistem birokrasi.

${ }^{8}$ Agus Dwiyanto, Mewujudkan Good Governance Melalui Pelayanan Publik (Yogyakarta: Gajah Mada University Press, 2006), hlm. 80 . 
Perwujudan good governance tergantung pada parapejabat yang terlibat di dalam governance itu sendiri, dan non pemerintah Aspek-aspek yang harus disentuh pun kompleks mencakup politik, sosial, budaya, dan ekonomi Dalam hal kelembagaan tentu saja perlu diupayakan terbentuknya relasi antar lembaga pemerintah dan non pemerintah bersifat check and balance. Sementara itu, di dalam tubuh birokrasi sendiri perlu dilakukan perubahan atau reformasi agar tercipta birokrasi yang professional. Birokrasi sebagai sistem terbuka tidak boleh menolak perubahan, tetapi harus selalu memperbaiki dirinya dalam suatu proses pembelajaran yang berkelanjutan

Terdapat tiga elemen di dalam tubuh birokrasi yang harus disentuh, yaitu organisasi, manajemen, dan personil. ${ }^{9}$ Pengembangan organisasi (Organization development) harus diarahkan untuk menghindari terjadinya pembentukan unit-unit kerja yang menghambat efektifitas dan efisiensi duplikasi tugas dan fungsi, serta yang sekedar menampung pegawai tanpa tugas dan fungsi yang jelas Selain itu, juga menghindari terjadinya penyeragaman bentuk dan unit keja yang tidak perlu tanpa memperhatikan kebutuhan dan analisis beban kerja yang sebenarnya.

Sistem manajemen mulai dari proses kebijakan hingga pedoman kerja bahkan sistem pengarsipan perlu dirumuskan ulang agar lebih realistis dan applicable. Sedangkan pegawai perlu dididik kembali di satu pihak dan diberi insentif yang memadai di pihak lain. Lebih baik memiliki sedikit pegawai dengan kualitas bagus dan digaji tinggi dari pada banyak pegawai dengan kualitas buruk yang digaji rendah.

Karena itu, berbagai program pendidikan dan pelatihan perlu ditata kembali untuk disesuaikan dengan kebutuhan nyata Perilaku pegawai perlu dibenahi agar berorientasi pada produktivitas dan kualitas kerja serta mengutamakan kepentingan masyarakat umum dan social equity, bukan kepentingan suatu kelompok atau partai yang berkuasa. Ini tentu saja terkait erat dengan sistem insentif dan pertanggungjawaban di dalam sistem administrasi secara keseluruhan.

\section{GOOD GOVERNANCE DALAM TINJAUAN PERSPEKTIF SYARI'AH DENGAN PENDEKATAN ILMU USUL FIQIH.}

Krisis yang dihadapi bangsa Indonesia sekarang ini sebagai suatu "krisis multidimensional yang berkepanjangan". ${ }^{10}$ Memang kita sebagai warga masyarakat biasa melihat dan merasakan betapa parahnya keterpurukan yang kita alami dalam berbagai bidang; Di bidang politik, krisisnya terlihat misalnya dalam kian melemahnya kepercayaan masyarakat terhadap birokrasi pemerintah. Krisis kepercayaan ini dapat dilihat dalam bermunculannya berbagai protes dan terjadinya sejumlah demonstrasi yang dilakukan oleh berbagai komponen masyarakat terhadap birokrasi baik di tingkat pusat maupun daerah yang menunjukkan adanya rasa ketidakpuasan terhadap kinerja birokrasi

Bangsa Indonesia kini dan sejak beberapa tahun silam, sedang menjalani proses reformasi, meskipun banyak kalangan merasa jalannya reformasi ini tidak seperti diharapkan. Namun paling tidak ada dua hasil reformasi ini tidak seperti yang diharapkan. Namun paling tidak ada dua hasil reformasi ini yang penting, yaitu berubahnya sistem pemerintahan Negara dari sentralisasi ke desentralisasi di mana "Pemerintahan daerah menjalankan otonomi seluasluasnya, kecuali urusan pemerintahan yang oleh undang-undang ditentukan sebagai urusan pemerintahan pusat, dan berubahnya paradigma birokrasi dari paradigma kekuasaan menjadi paradigma pelayanan.

${ }^{9}$ Ely Susanto, Otonomi Daerah Peluang dan Problematikanya dalam Pembangunan Birokrasi Daerah (Yogyakarta: MAP UGM. 2002), hlm. 126-127.

${ }^{10}$ Dwiyanto dkk, Reformasi Tata Pemerintahan don Otonomi Daerah (Yogyakarta: Pusat Studi Kependudukan dan Kebijakan. UGM, 2003), hlm. 1 
Dalam rangka terus mendorong roda reformasi, dalam kaitannya dengan penyelenggaraan birokrasi pemerintahan adalah apa yang dikenal dengan good governance (kepemerintahan yang baik atau tata pemerintahan yang baik). ${ }^{11}$ Sebenarnya istilah good governance tidak hanya berkonotasi pengelolaan birokrasi pemerintahan saja. tetapi lebih luas dari itu. mencakup seluruh pengelolaan haik pengelolaan pemerintahan maupun pengelolaan instansi atau organisasi swasta khususnya yang berkaitan dengan pelayanan umum.

Dengan demikian sesungguhnya istilah governance lebih tepat diterjemahkan sebagai tata kelola. Namun harus diakui bahwa istilah good governance ini dalam pemakaian oleh para pengkaji lebih banyak digunakan dalam pembicaraan tata kelola pemerintahan yang baik Hal ini juga disebabkan oleh karena diskusi tentang peran institusi dalam pembangunan didominasi oleh analisis mengenai peran Negara

Konsep tata kelola pemerintahan yang baik semula banyak diusung oleh lembagalembaga bantuan internasional dalam rangka upaya mengefektifkan dan menyukseskan program-program bantuan mereka di negara-negara dunia ketiga yang banyak mengalami kegagalan Kegagalan tersebut disebabkan oleh buruknya sistem penyelenggaraan pemerintahan di negara-negara dunia ketiga tersebut yang ditandai dengan maraknya praktik korupsi, kolusi, nepotisme dan penyalahgunaan kekuasaan Konsep tata kelola pemerintahan yang baik (good governance) dimaksudkan sebagai perbaikan dan perluasan terhadap konsep pemerintahan (govermenl) selama ini yang dipandang tidak memadai. ${ }^{12}$

Good governance didasarkan kepada sekumpulan nilai atau prinsip yang dijadikan kriteria acuan untuk menilai apakah suatu tata pemerintahan baik atau tidak. Ada beberapa definisi yang diberikan kepada governance. UNDP mendefinisikannya sebagai "penggunaan kewenangan politik, ekonomi, dan administrative untuk mengelola urusan suatu bangsa pada semua peringkat, the exercise of political, economic, and administrative authority to manage a nation's affair at all levels."

Konsep governance (tata kelola pemerintahan) merupakan perluasan dari konsep pemerintah (goverment) karena di dalam yang pertama, yaitu governance, terkandung pengertian bahwa pemerintahan tidak hanya diselenggarakan oleh pemerintah (goverment) sendiri tetapi juga bersama-sama dengan aktor-aktor di luar pemerintah, yaitu masyarakat secara luas sebagai stakeholders.

Hal ini disebabkan oleh karena adanya anggapan bahwa pemerintah sendiri dirasakan tidak memadai, mengingat kompleksitas kehidupan masayarakat yang menuntut adanya perubahan praktik pemerintahan dari yang semula didominasi oleh pemerintah menjadi sebuah tata pemerintahan yang membagi otoritas antara pemerintah dan masyarakat secara proporsional. ${ }^{13}$

Para ahli mengakui bahwa sesungguhnya "tidak ada struktur pemerintahan terbaik yang dapat diidentifikasi dengan jelas untuk digunakan sebagai sebuah model universal bagi negaranegara berkembang. ${ }^{14}$ Akan tetapi setidaknya beberapa ciri dapat diidentifikasi untuk yang menandai apa yang disebut good governance.

${ }^{11}$ Sedamayanti, Good Governance (Kepemimpinan yang Baik) dalam Rangka Otonomi Daerah (Bandung: Penerbit Mandar maju, 2003), hlm. 4

12 Dwiyanto dkk, Reformasi Tata Pemerintahan dan Otonomi Daerah (Yogyakarta: Pusat Studi Kependudukan dan Kebijakan, UGM, 2003), him. 3 dan 4.

${ }^{13}$ Ibid., hlm. 4.

${ }^{14}$ Satish Chandra Mishra, "Pemerintah dan Pemerintahan: Memahami Ekonomi Politik Reformasi Institusi, "Jurnal reformau Ekonomi, Vol. 1, No 2 (Oktober Desember. 2000), hlm. 42. 
Agar suatu tata kelola pemerintahan yang baik terwujud, maka norma-norma yang harus dipenuhi adalah adanya partisipasi, efisiensi, keadilan dan kepastian hukum, akuntabilitas, transparansi, responsifitas, dan adanya visi

Menurut pandangan syari'ah suatu pengertian governance termaktub dalam ayat alQur'an yang berbunyi:

15

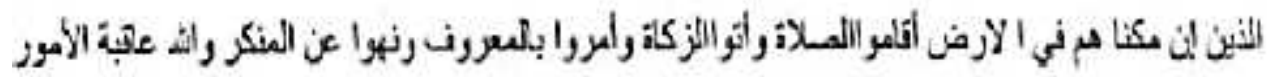

Artinya:

(yaitu) orang-orang yang jika Kami teguhkan kekuasaan mereka di muka bumi, niscaya mereka mendirikan sembahyang, menunaikan zakat, menyuruh berbuat yang ma'nif dan mencegah dari perbuatan yang mungkar, dan kepada Allah-lah kembali segala urusan.

Dengan menangkap dalalah al-isya'rah ar-ramziyah dari ayat ini kita dapat melihat bahwa governance dalam perspektif syari'ah adalah suatu penggunaan otoritas kekuasaan untuk mengelola pembangunan yang berorientasi pada (1) penciptaan suasana kondusif bagi masyarakat untuk pemenuhan kebutuhan spiritual dan rohaniahnya sebagaimana disimbolkan oleh penegakan salat, (2) penciptaan kemakmuran dan kesejahteraan ekonomi sebagaimana dilambangkan oleh tindakan membayar zakat, dan (3) penciptaan stabilitas politik dan keamanan sebagaimana diilhamkan oleh tindakan amar ma'ruf nahi munkar. Singkat kata dalam ayat tersebut terdapat tiga aspek governance, yaitu: (1) spiritualgovernance, (2) economic governance, dan (3) politicalgovernance.

Untuk dapat mewujudkan good governance dalam tiga aspek tersebut diperlukan beberapa nilai dan dari nilai itu dapat ditumnkan beberapa asas tata kelola pemerintahan yang baik. Dengan memperhatikan ayat-ayat al-Qur'an dan Sunnah Nabi SAW dpat ditemukan beberapa nilai-nilai dasar yang dapat dijabarkan menjadi asas-asas tata kelola pemerintahan yang baik, yaitu syura, meninggalkan yang tidak bernilai guna, keadilan, ukhuwah, dan amanah.

Nilai dasar pertama, yaitu syura, ditegaskan di dalam alqur'an;

Artinya:

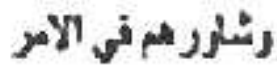

Dan bermusyawarahlah dengan mereka dalam urusan itu.

Dari nilai dasar syura ini dapat diturunkan asas hukum mengenai penyelenggaraan pemerintahan berupa asas partisipasi masyarakat. Adanya partisipasi masyarakat luas dalam mengambil keputusan dan membuat kebijakan adalah salah satu prinsip penting good goxrrnance. Masyarakat tidak hanya dijadikan sebagai obyek belaka dari suatu keputusan atau kebijakan, tetapi juga merupakan pelaku signifikan di dalam proses tersebut.

Hal ini diharapkan dapat memberikan legitimasi lebih besar dan dukungan kuat terhadap keputusan dan kebijakan yang diambil. Dalam kaitan dengan kepemimpinan, menjadi suatu ukuran keidealan pemimpin apabila ia dapat melibatkan seluas mungkin partisipasi warga masyarakat dalam berbagai keputusan.

Nilai dasar berikutnya dalam hukum Islam adalah penegasan Nabi SAW mengenai meninggalkan segala yang tidak bernilai guna. Nabi bersabda;

${ }^{15}$ Al Haijj (22): 41 
Artinya:

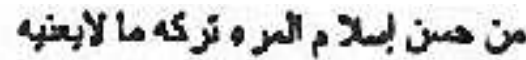

Sebaik-baik Islam seseorang adalah bahwa ia meninggalkan hal-hal yang tidak berguna (HR At-tirmidzi dan Ahmad).

Dari hadis ini dapat diturunkan asas efisiensi dalam penyelenggaran kepentingan publik (bahkan kepentingan diri sendiri juga). Efisiensi merupakan kesesuaian hasil dari suatu proses dengan apa yang telah digariiUn dengan menggunakan sumber yang ada sebaik mungkin. Dengan kau lain efisiensi adalah keselarasan antara masukan dan keluaran. Seorang pemimpin secara normative dituntut untuk dapat menegakkan efisiensi dalam manajemennya sehingga hasil-hasil pembangunan yang dibuat benar-benar berkualitas dan sesuai dengan dana masyarakat yang dikeluarkan.

Dalam kaitan dengan pelayanan birokrasi terhadap masyarakat efisiensi akan terlihat pada ringannya biaya pengurusan dim singkatnya waktu yang dihabiskan anggota masyarakat untuk suatu pelayanan yang berkualitas Pelayanan yang tidak efisien ini mungkin juga bersumber dari paradigma birokrasi sebagai kekuasaan, bukan sebagai pelayanan. Dalam konteks Islam ada sebuah hadis yang berbunyi;

Artinya;

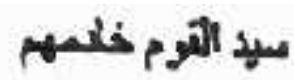

Pemimpin suatu kaum adalah pelayan mereka (HR. ad-Dailani dan al-Qazwini).

Jadi birokrasi sebenarnya adalah sebuah pelayanan, bukan sebuah kekuasaan Sebaliknya dalam paradigma kekuasaan, masyarakat sebagai konsumen layanan berkedudukan lemah dan tidak dapat menuntut hak-haknya sebagaimana mestinya Akhirnya dari kondisi ini muncul praktik suap dalam penyelenggaraan pelayanan umum

Yang lebih buruk lagi praktik ini telah membudaya dalam arti bahwa tumbuh pemahaman umum pada pemberi pelayanan bahwa uang imbalan semacam itu adalah suatu yang wajar atas jasanya memberikan pelayanan dan masyarakat penerima layanan itupun juga merasa diuntungkan dan merasa wajar pula untuk mengeluarkan imbalan sebagai balas jasa

Nilai dasar lain dalam hukum Islam adalah keadilan Penegasan mengenai keadilan di dalam sumber-sumber Islam banyak sekali, misalnya dalam al-Qur'an,

Artinya,

16

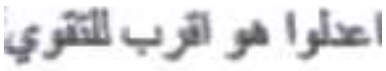

Berbuat adillah kamu. karena berbuat adil itu lebih dekat kepada taqwa Dalam ayat lain dikatakan.

Artinya.

17

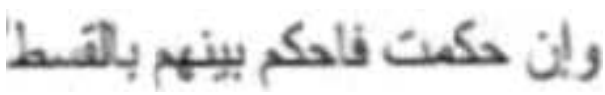

Dan apabila kamu memberi keputusan, hendaklah kamu memutuskan dengan adil

Masalah keadilan secara umum dan masalah kepastian hukum merupakan jeritan seluruh masyarakat Indonesia saat ini. Tata kelola pemerintahan yang baik menghendaki adanya jaminan kesamaan akses seluruh warga masyarakat terhadap sumber daya politik, ekonomi dan administratif. Pemimpin yang membiarkan perlakuan diskriminatif terhadap warganya dalam akses ini berarti tidak menjalankan prinsip kepemerintahan yang baik. Konsentrasi sumber daya ekonomi pada orang atau kelompok tertentu karena kolusi dan nepotisme adalah tanda dari kepemimpinan yang buruk Untuk mengakses jabatan publik seperti ingin menjadi pegawai

\footnotetext{
${ }^{16}$ Al-maidah (4): 8.
}

${ }^{17}$ Al-maidah (4):58.. 
misalnya orang harus mengeluarkan sejumlah uang dan yang tidak mampu mengeluarkan uang tidak akan memperolehnya, meskipun ia memiliki keunggulan yang sangat potensial

Dalam hukum Islam, cabang dari asas keadilan adalah asas perlakuan yang sama (almumalah bi al-misl). ${ }^{18}$ Perlakuan yang sama dalam hukum Islam menjadi landasan hubungan

antar manusia termasuk dalam pemberian pelayanan Menegaskan asas perlakuan yang sama ini. Nabi SAW bersabda.

Artinya;

Perlakuan manusia dengan perlakuan mereka yang sama (HR al-Hakim)

Dari konsep al-ukhuwwah sebagai salah satu nilai dasar svari'ah dapat diturunkan asas responsivitas dalam pemberian pelayanan Secara khusus asas ini dapat pula disimpulkan dari firman Allah yang menggambarkan pribadi Rasullullah SAW yang sensitive atas penderitaan umatnya

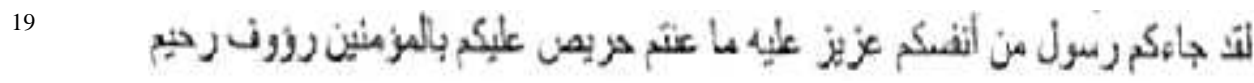

Artinya:

Telah datang kepadamu seorang utusan (rasul) dari kalanganmu sendiri, berat dirasakannya apa yang kamu derita, sangat memperhatikan kamu dan amat belas kasih lagi penyayang terhadap orang-orang mukmin

Responsivitas terhadap aspirasi dan kebutuhan masyarakat adalah ciri lain dari good governance. Seorang pemimipin dengan birokrasinya harus merupakan sosok yang tanggap terhadap bei bagai aspirasi dan tuntutan masyarakat

Dalam al-Qur'an Allah berfirman,

$$
\text { Artinya }
$$

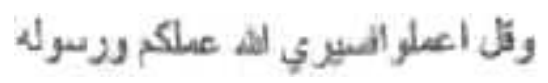

Dan katakanlah Bekerjalah kamu, maka Allah, Rasul-Nya dan oring-orang mukmin akan melihat pekerjaanmu itu

Ayat tersebut menegaskan keharusan bekerja sebagaimana mestinya dan pekerjaan itu diawasi oleh Allah, RasulNya dan orang-orang mukmin Pengertian isyarat(dalalah isyarah) ayat ini adalah bahwa karena diawasi, maka itu berarti bahwa pelaksanaan pekerjaan harus akuntabel Dari ayat itu juga dapat disimpulkan asas transparansi karena dilihat oleh Allah, Rasul-Nya dan orang-orang mukmin Selain itu nilai dasar hukum Islam lainnya adalah amanah Di dalam konsep amanah itu terdapat suatu asas akuntabilitas. Di sisi lain al-Qur'an menegaskan

$$
\text { Artinya: }
$$$$
21
$$

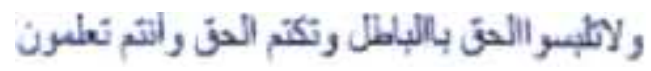

Dan janganlah kamu menyembunyikan kebenaran, padahal kamu mengetahui

\footnotetext{
${ }^{18}$ Abu Zahrah,al-'Ilaqat od-Dauliyah fi al-lslam (Mesir: Dir al-Fikr al-'Arabi), hlm. 36.

${ }^{19}$ At-Taubah (9): 128.

${ }^{20}$ At-Taubah (9): 105

${ }^{21}$ AI-Baqarah (2): 42
} 
Salah satu pengertian yang dapat ditarik dari keumuman pernyataan ayat ini adalah adanya asas transparansi termasuk di dalam transparansi dalam penyelenggaraan birokrasi untuk melayani publik Akuntabilitas dan transparansi adalah kriteria lainnya yang penting dalam suatu good governance. Kebijakan publik harus bersifat transparan dan diambil dengan mengacu kepada kepentingan masyarakat secara luas. sehingga dengan demikian ia memiliki akuntabilitas yang tinggi. Kurangnya transparansi dalam penentuan kebijakan publik dan tidak dijadikannya kepentingan masyarakat luas sebagai acuannya menjadi sumber maraknya praktik KKN dalam penyelenggaraan pemerintah di Indonesia sekarang Ini pula yang merupakan salah satu masalah terbesar di Indonesia dan yang menyebabkan keterpurukan bangsa di berbagai aspek.

Dunia internasional mempersepsikan Indonesia sebagai Negara yang amat korup Transperansi International menempatkan Indonesia sebagai Negara terkorup kelima dari 90 negara. Political dan Economic Risk Consulting menempatkan Indonesia sebagai Negara terkorup di Asia. ${ }^{22}$

Akhirnya adanya visi strategis merupakan prinsip kepemerintahan yang baik. Visi adalah gambaran mengenai masa depan yang dikonseptualisasikan dan yang hendak diwujudkan Seorang pemimpin tidak hanya harus mampu merumuskan gambaran masa depan yang hendak diwujudkan Seorang pemimpin tidak hanya mampu merumuskan gambaran masa depan yang hendak diwujudkan tetapi juga harus mampu meyakinkan, mengelola dan menyatukan potensi masyarakat untuk bersama-sama melakukan upava guna mewujudkan visi tersebut.

\section{PENUTUP}

Good governance sangat mendesak untuk diwujudkan pada penyelenggaraan pemerintahan dan pelayanan publik di tingkat propinsi dan kabupaten/kota mengingat banyak kewenangan telah diserahkan kepada pemerintah di kedua level ini Kedudukan daerah sangat strategis dalam mempertahankan keutuhan bangsa sekaligus sebagai garda depan untuk menciptakan Indonesia yang satu dan makmur secara lebih konkret Pemerintah kabupaten/kota dan propinsi merupakan figure kunci perwujudan good governance, yaitu sebagai koordinator bagi institusi semi-pemerintah dan non-pemerintah untuk bersama-sama membentuk kolaborasi yang efektif mengatasi permasalahan dan memenuhi kebutuhan masyarakat

Langkah terdekat yang perlu dilakukan pemerintah propinsi dan kabupaten/kota guna mewujudkan good governance adalah melakukan pembenahan terhadap kelembagaannya sendiri serta mengobati penyakit yang di idapnya

${ }^{22}$ Sudirman Said dan Nizar Suhendra, Korupsi dan Budaya Masyarakat Indonesia, dalam Hamid Basyaib dkk, Mencuci Uang Rakyat 16 Kajian Korupsi. di Indonesia (Jakarta: Aksara Foundation, 2002), hlm. 110-111 


\section{DAFTAR PUSTAKA}

Dwiyanto dkk. Reformasi Tata Pemerintahan dan Otonomi Daerah Yogyakarta. Pusat Studi Kependudukan dan Kebijakan, UGM. 2003

Dwiyanto, Agus, Teladan dan Pantangan dalam Penyelenggaraan pemerintahan dan Otonomi Daerah Yogyakarta PSKK UGM, 2003

Irfan, Muhammad Akuntabilitas dan Good Governance Jakarta Departeman RI Sekretariat Jenderal Biro Organisasi dan Tata laksana, 2007.

Mishra. Chandra Satish, "Pemerintah dan Pemerintahan: Memahami Ekonomi Politik Reformasi Institusi, "Jurnal reformasi Ekonomi, Vol. I, No 2 Oktober-Desember 2000

Motzki, Haraid, 'The Origins of Islamic Jurisprudence: Meccan Tiqih before the Classical Schools Leiden-Boston-Koln Brill, 2002

Said, Sudirman, dan Suhendra, Nizar, Korupsi dan Budaya Masyarakat Indonesia, dalam Hamid Basyaib dkk, Mencuci Hang Rakyat: 16 Kapan Korupsi di Indonesia Jakarta: Aksara Foundation. 2002.

Sedamayanti, Good Governance (Kepemimpinan yang Haik) dalam Rangka Otonomi Daerah Bandung: Penerbit Mandar maju, 2003.

Susanto, Ely. Otonomi Daerah Peluang dan Problematikannya dalam Pembangunan Birokrasi Daerah Yogyakarta: MAP UGM. 2002

Zahrah, Abu, al-llaqat ad-Dauliyah fi al-lslam Mesir: Dar al-Fikr al-'Arabi 